\section{Price Risk Management by Futures Markets and Public Warehousing}

\author{
László Kozár ${ }^{1}$ - Lóránt Fodor ${ }^{2}$ \\ ${ }^{1}$ University of Debrecen, Centre for Agricultural Sciences, \\ Faculty of Agricultural Economics and Rural Development, \\ Department of Marketing and Business, Debrecen \\ ${ }^{2}$ University of Veszprem, \\ Georgikon Faculty of Agriculture, Keszthely \\ kozart69@freemail.hu
}

\section{SUMMARY}

The principal achievement of this paper is the combinative use of two market institutions: public warehousing and commodity exchange and how their joint application is beneficial for the players on the grain market. Based on a theoretical foundation, a calculation model was developed in order to assist short and longterm marketing decisions. It allows all the three participants of the market: producers, consumers and traders, to use this model in order to establish their own business strategy. The model can be used to analyse factors influencing the establishment of price; therefore, it can be also used for policy-making decisions.

Keywords: Public Warehousing, Commodity Exchange, grain marketing, Lombard financing

\section{INTRODUCTION AND PROBLEM DEFINI- TION}

There are different possibilities for agricultural firms to manage their risks business. The risk of agricultural production contains several components. The protection against them needs different tools and has different chances. Protection against production risks needs different tools than protection against price or market risks. It is known that farmers consider market risks more important than production risks.
German farmers spend maximum 40 per cent of their work time with production, and minimum 60 per cent with sales, and this latter percentage ratio is growing year by year. This shows that farmers in Germany have realized that market risk management must be the part of their business activity.

In the case where there are appropriate marketing institutions - such as a Commodity Exchange or a Public Warehouse - commercial and financial risks can be managed, achieving much a lower level than natural risks, such as drought or contagious disease.

Market institutions in the form of a Commodity Exchange and a Public Warehouse in Hungary are presented in this paper we detail market risk management methods and offer possibilities for practice.

\section{SECONDARY LITERATURE ANALYSIS}

Because of the nature of agricultural production, there are several different risks producers must handle. These risks can be production (natural and technical) or economic risks. The probability of the risk causes a problem for the market participants day by day (Krugman, 1994).

The risks of agricultural firms can be divided into two big groups, according to their nature, as shown in Figure 1.

Figure 1: Risk factors and their effect in agriculture

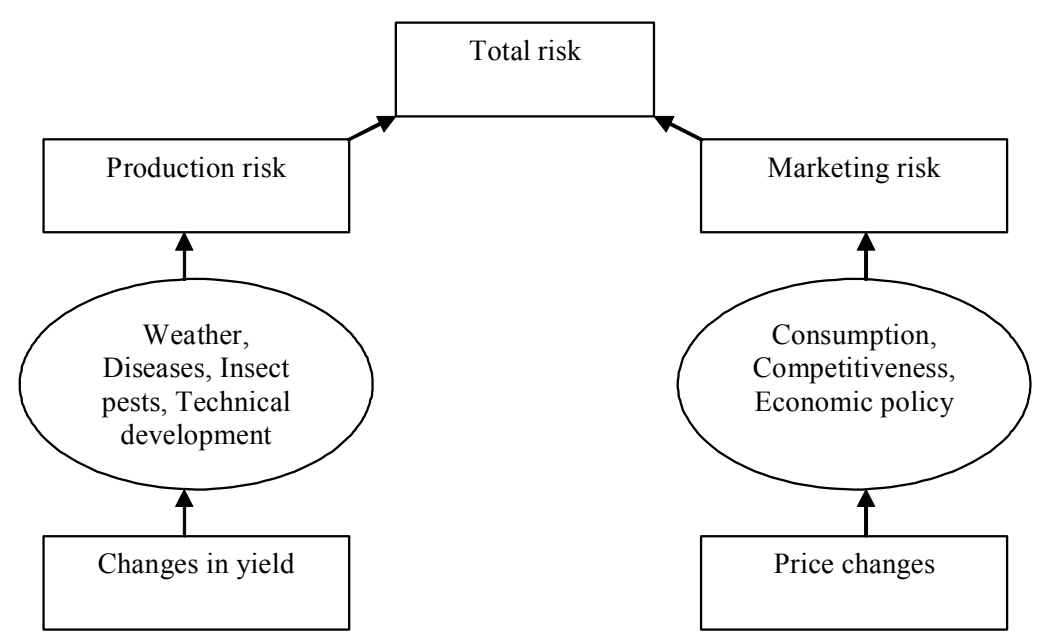


Managers of agricultural firms use the two categories of uncertancy and risk as synonyms (Kemény, 2001).

The risk management strategies of agricultural enterprises according to Castle, Becker, and Nelson (1992) are the following:

- Flexibility

- Tenancy

- Marketing possibilities

- Financial management alternatives

- Insurance

Price risk has become a more immediate issue for both farmers and agribusiness companies in the United States and European Union, due to WTO free trade policies and the agricultural policy reforms stipulated by the EU (Pennings and Meulenberg, 1997).

The result of the monitoring of the budget CAP in the middle of the fiscal period 2000-2006 (MTR, Middle Term Revenue) led to the new reform CAP. The most important element of this reform is to separate direct payments - the biggest amount of the budget - from production (decoupling) and to transfer to rural these to development goals (modulation). This arrangement is forcing the development of market circumstances in the grain sector definitely (Vajda, 2003).

The foundations of current Public Warehousing originated in England (Fisher, 1908). There are three different varieties of storage buildings in England: Docks around a port, Wharfs in ports and Warehouse fares from ports (Minch, 1928).

Warehouses were established for trading purposes in Belgium, the Netherlands, and France, in the $17^{\text {th }}$ century, and their prosperity was successful without any legal regulation (Máygráber, 1865).

Hungary was the first country in Europe where Public Warehousing was handled as a trading activity on Act level. The Trading Act was passed at 1875 . According to the act: „Public Warehouse is a company, dealing with the storage of merchandise and issuing warehouse recipes" (Kelényi, 1994, Csőke, 1996). Recently, public warehouses have become special financial institutes with a licence to issue a particular security: Warehouse Recipe (Bács and Kozár, 2002).

Modern futures trading started in Chicago. The Chicago Board of Trade was founded in 1848; trading with futures contracts started in 1865 (Barry, 1984). The „Grain Hall of Pest”, the original Hungarian Commodity Exchange, was founded in 1853; from 1864, the name changed to The Budapest Commodity and Stock Exchange (Bozzai, 1988). Recently, the Budapest Commodity Exchange had more than a hundred members, and the turnover in grain futures contracts are in millions of tonnes (Fodor, 2002).

Given the increased agricultural price fluctuations, some exchanges in Europe, such as the Amsterdam Agricultural Futures Exchange, the London Commodity Exchange, the Warenterminborse in Hannover and the Warsaw Board of Trade, are preparing to introduce new agricultural futures contracts (Pennings and Meulenberg, 1997). It can be established from the literature that protection against price volatility has always been in the interest of the authors.

\section{OBJECTIVES AND CONCEPTUAL FRAMEWORK}

The goal of this paper is to present the economic and commercial situation of the above mentioned two important market institutions and the future possibilities in the EU.

Although both of the institutions are enough important to analyse them independently, this paper presents their combined applications.

The main goal of the paper is to present the possibilities of two fields together and to find the possible connections between them from the market participants' point of view. There is no intention in the article to analyze agricultural and currency policy decisions on a macroeconomic level or far possible reforms of the EU trade and agricultural policy. The present situation is accepted as a given circle of circumstances, the paper focuses on the connections and the possibilities of the technical background of the institutions mentioned above.

The possibility of the combined application of these market institutions from the grain producers' point of view is shown in the paper.

In the characterisation of different commercial methods the combination of lombard financing and the futures hedging is illustrated.

The most important goal of the paper overall is to present a calculation model which can be useful for any participant at the same time in the grain business, such as by producers, consumers and traders.

The model is a useful tool to calculate the basic price information for the short term business decisions and for mid-term strategy.

\section{CHARACTERISATION OF DIFFERENT COMMERCIAL METHODS}

The traditional me that of commodity marketing is shown in Figure 2.

Figure 2: Traditional commodity marketing

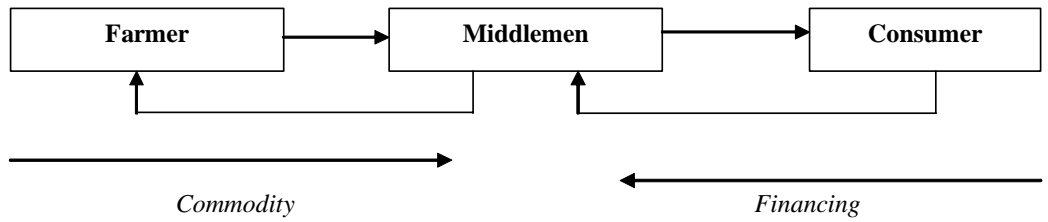


The public warehouse-based Lombard financing has had great importance in financing the grain market during the last several years in Hungary. This method is very similar to the characteristic US method, and is presented in Figure 3.

Figure 3: Public warehouse-based commodity marketing

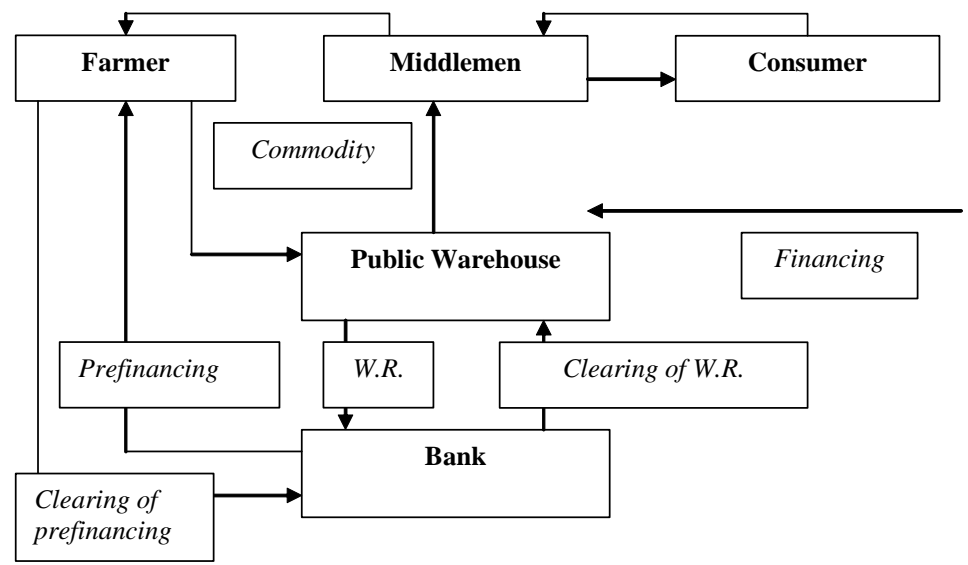

Source: Own figure

The present practice of Lombard financing has been developed for more than ten years, and by now it has became a day-by-day used financing system. Most of the Hungarian commercial banks are dealing in this type of business.

The Commodity Exchange is in a special situation in Hungary. This market - organised according to the large American Exchanges corresponds to the strictest expectations by its service, technique, organization and guaranties. The entire market uses the prices of the given Commodity
Exchange as target prices for production agreements, trading contracts as well as Lombard credit financing, and there are participants on the market, from the hedging to the speculating side, as well. This market has a bigger turnover in grain futures contracts than the other European markets such as Marché A Terme d'Instruments Financiers (MATIF), and the other members of the EURONET.

The traditional method of commodity marketing with a short hedge is shown in Figure 4.

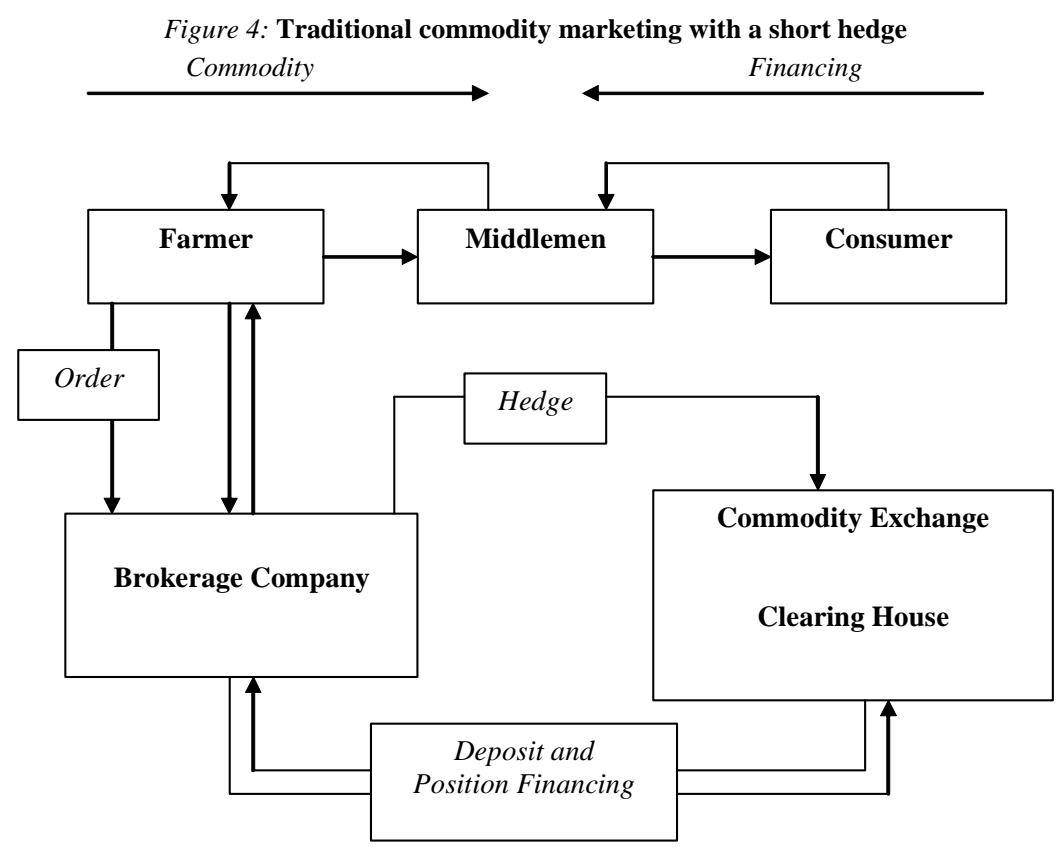

Source: Own figure

The institutes of public warehousing and futures market are available for the participants on the grain market in Hungary and in several other European countries. The combination of possibilities offered by the two institutes gives the biggest chance to eliminate price risks. In the case of Lombard credits, it gives the best opportunity for both the borrower and the bank, namely: the borrower can have the highest credit amount as the lowest risk for the bank. This construction is called as a Lombard credit with a futures hedge background.

The method of commodity marketing by combination of public warehouse and a short hedge is shown in Figure 5. 
Figure 5: Public Warehouse-based commodity marketing with a short hedge Commodity Financing

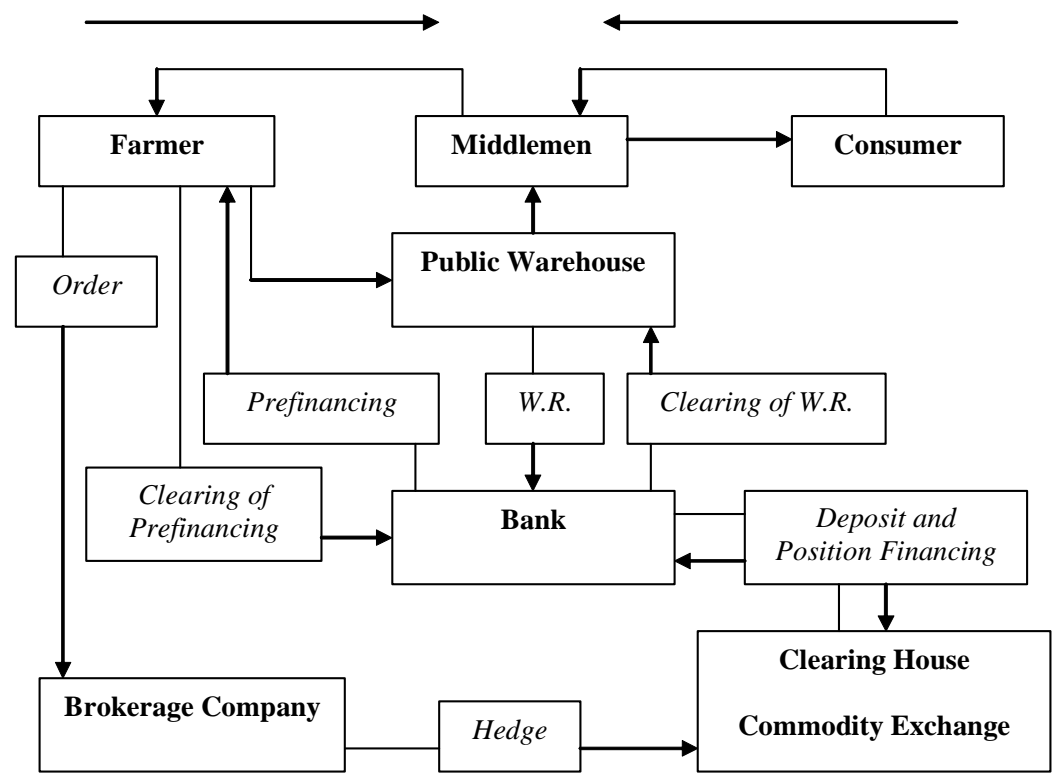

Source: Own figure

The institutes and the possibility to use the combination of advantages offered by them are available to all producers, traders and consumers.

The most important basic information required to do business is the price of the commodity. This determines the profit of the business. There is no such a thing as ,average" price information, because of the parity, storage, finance and logistics. Knowing the special conditions of a given market, it is possible, however, to prepare precise price calculations for selling, purchasing or production decisions for that market.

To find the relevant answer to these questions, a calculation model was created and all of the price influencing factors are built in. The goal of using this model from the producers', traders' and consumers' point of view is to calculate daily price information to decide on immediate selling/buying or a postponed selling/buying of the commodity, based on public warehousing and futures hedge information.

\section{METHODOLOGY OF THE DECISION- MAKING MODEL}

The function of the model is to give up-to-date price information based on the principles described above and daily information about price influencing factors for any participant of grain market.

\subsection{Inputs of the model}

The inputs of the model can be shared into two parts: the medium-term principal inputs (e.g. railway tariffs), and the daily-modified information (e.g. currency exchange rate).

The main inputs are, as below:

- Primary cost: Pc: $(€ / t)$ the cost of the production of one metric ton of the commodity (in local currency). This is the basis for the price calculation (in the case of a producer).

In case of consumer: Purchasing price: Pp (in local currency).

In case of trader: Pp, or Selling price: Sp (in chosen foreign currency).

The price calculation is prepared in one direction in the case of a producer and consumer, but it can be prepared in two directions, as well, in the case of a trader.

- Foreign currency: Fc: $(€ / c)$ the currency of the offer or the contract. It is usually USD, but any other currency can be used.

- Inputs, connected to the storage:

Sf: storage fee (€/month), in the case of self owned storage capacity its primary cost per ton.

St: storage time (month).

Ff: fumigation fee (€/case).

Fp: fumigation period (case).

- Inputs, connected to public warehousing:

Wf: warehouse fee (€/month).

Wp: warehousing period (month).

Wo: other additional costs, for example: additional insurance cost $(€ / t)$.

- Inputs, connected to financing:

Ir: interest rate of the financing $(\% / y e a r$, the real rate according to the credit contract, or the average bank interest rate).

Fp: financing period (month).

Fo: other financing costs: additional bank fees $(€ / t)$.

- Inputs, connected to Commodity Exchange:

Bf: Brokerage fee, containing the direct fee of Brokerage Company, the fee of Exchange and the fee of Clearing House $(€ / \mathrm{t})$.

Id: interest of daily exchange rate differences: $(\% /$ year $)=$ Ir.

Pr+, Pr0, Pr-, direction of financing of the daily exchange rate differences. 
Fp: Futures period (month), the real open period of the futures contract.

\section{- Inputs, connected to transportation:}

Rd: Railway distance: $(\mathrm{km})$, distance from the actual loading point to the border.

Cl: Carriage loading: cost of the loading of railway carriage $(€ / t)$.

Rf: Railway freight: the official freight tariffs of the actual Railway Company $(€ / t)$.

Tf: Truck Freight: $(€ / \mathrm{t} / \mathrm{km})$, freightage of the Truck Company.

Td: Trucking distance: $(\mathrm{km})$, the exact carriage distance by truck.

Tl: Truck loading: cost of the loading of truck $(€ / \mathrm{t})$.

- Inputs, at the port $(€ / t)$ :

L: Loading, from truck or rail carriage into the ship/barge.

S: Scaling, the fee of official scaling.

W: Wharfage, the fees of using wharf during loading.

D: Documentation, costs of documents issuing at the port (duty, etc.).

- Quality and health certificates ( $€ / t)$ :

Q: The fee of Quality Certificate.

Pl: The fee of local Phytosanitary Certificate.

Pe: The fee of export Phytosanitary Certificate.

Ve: The fee of export Veterinary Certificate.

- Profit: P: the amount of desired profit $(€ / t)$.

\subsection{Outputs of the model}

The model uses the information of principal database first. The pre-calculatory outputs of this calculation gives immediate information for the user, and the final cost and price calculation will be based on these results, as well as the other primary inputs (see above).

The pre-calculation outputs are, as follows:

- Storage cost, $S:(€ / t)$

- Public Warehousing cost, W: $(€ / \mathrm{t})$

- Financing cost, F: $(€ / \mathrm{t})$

- Cost of the Commodity Exchange, E: $(€ / t)$. The model calculates the cost of the daily financing based on the daily exchange rate differences. In case of:

E1 (Pr+): the futures position needs financing during the whole period, which is not more than 50 per cent, according to long-term practice.

E2 (Pr-): the opposite situation, the exchange price difference generates income.

The possibilities of E1 and E2 are the similar in the daily business.

E3 (Pr0): the costs and incomes eliminate each other.

- Railway cost, R: (€/t)

Railway costs cannot be calculated on a $€ / \mathrm{km}$ basis, because the freight cost is not linear with the length of transportation. Because of this, the model uses the official freight tariffs of the actual Railway Company as a principal data base, and chooses the actual cost according to the railway distance.

The loading of railway carriage is not the part of the railway cost, since it is an independent output.

- Trucking cost, $T:(€ / t)$

- Cost of the port, P: $(€ / t)$

- Agent's cost, A: $(€ / t)$

- Foreign currency, Fc: $(€ / c)$ the currency of the offer or the contract. It is usually $\$$, but any other currencies can also be used.

Final calculation can be prepared after the precalculation phase, using the chosen pre-calculation outputs and the other chosen inputs, as a database.

Final outputs are, as below:

- Primary cost, Pc: $(€ / t)$ the cost of the production of one metric ton of the commodity (in local currency). This is the basis for the price calculation (in case of a producer).

In case of a consumer: Purchasing price: $\mathbf{P p}$ (in local currency).

In case of a trader: Pp, or Selling price: Sp (in chosen foreign currency).

- In case of a producer the final output is the selling price: Sp in $€$, and in the given foreign currency, as well. The model shows the actual parity of the INCOTERMS, too.

- In case of a costumer the final output is the Purchasing cost: Pc in $€$ which contains the purchasing price and the additional costs of purchasing.

- In case of a trader the final output is the selling price: $\mathbf{S p}$ in the given foreign currency if there is Purchasing price: $\mathbf{P p}$ in the input side, or Purchasing price: $\mathbf{P p}$ in $€$, if there is a selling price: $S p$ at the input side.

If there is no price information on the input side, the output is the logistic cost: Lc in the given foreign currency. The model shows the parity of INCOTERMS, too, according to the actual price information.

\section{RESULTS OF THE MODEL}

Calculations have been prepared in two different parts:

6.1. The first part of calculation has been prepared using real price information from the Budapest Commodity Exchange. The goal to use this information was to provide a background for futures business decisions.

In this theoretical case, the calculation was prepared from the producers' point-of-view for milling wheat. Selling decision between immediate selling (selling price: $98.80 € / \mathrm{t}$, containing $10 € / \mathrm{t}$ profit) or postponed selling by May (in EXW parity) and the possibility to make a (May-term) futures hedge by August. Storage and Lombard financing period is 270 days. 
Figure 6: Chart of futures prices of milling wheat in the May 2004 term; from 1 August 2003 to 30 April 2004

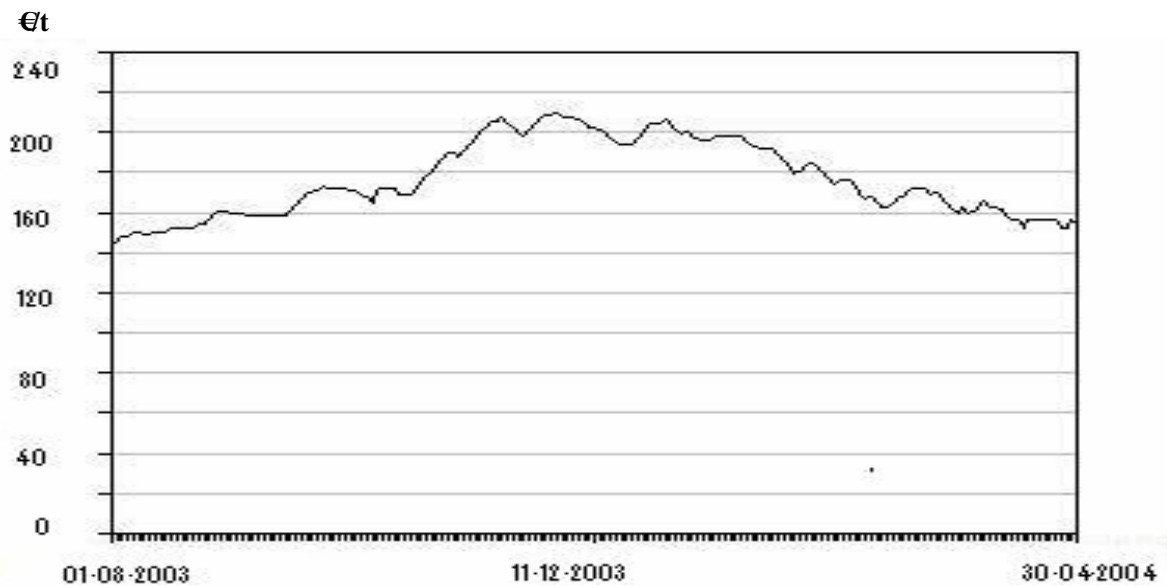

Source: Database of Budapest Commodity Exchange, 2004

\section{Inputs of the calculation:}

Primary cost of wheat:

Storage:

Fumigation (4 cases):

Warehouse fee:

Other warehousing costs:

Interest rate (according to Hungarian practice):

Brokerage fee:

Interest of daily exchange rate differences: $(=\mathbf{I r})$

Profit Expected:

Outputs of the calculation:

Primary cost of wheat:

Storage cost:

Public warehousing cost:

Financing cost:

Cost of the Commodity Exchange:

Profit Expected:

\section{Calculated selling price:}

The possible immediate selling price:

The (2004) May-term futures price is: $142 € / \mathrm{t}$. The calculated selling price is: $119.83 € / \mathrm{t}$ with $6.8 € / \mathrm{t}$ profit in it. The futures price contains $28.97 € / \mathrm{t}$ profit. The relevant business strategy is the postponed selling, hedging in the futures market and a bridging finance by Lombard credit.

\section{Inputs of the calculation:}

Primary cost of wheat:

Storage:

Fumigation 3 month storage (1 case):

Fumigation 6 month storage ( 2 case):

Fumigation 9 month storage (4 case):

Warehouse fee:

Other warehousing costs:

Interest rate (according to an average European level):

\section{Brokerage fee:}

Interest of daily exchange rate differences: $(=\mathbf{I r})$

Profit Expected:

Parity:

The possible immediate selling price:

The goal of the calculation is to test the efficiency of different price influence factors. The outcome of
Pc: $88 € / \mathrm{t}$

Sf: $0.76 € / \mathrm{t} / \mathrm{month}$

Ff: $0.88 € / \mathrm{t} / \mathrm{case}$

Wf: $0.14 € / \mathrm{t} / \mathrm{month}$

Wo: $0.1 € / \mathrm{t}$

Ir: $13 \%$

Bf: $0.44 € / \mathrm{t}$

Id: $13 \%$

P: $6.8 € / \mathrm{t}$

Pc: $88 € / \mathbf{t}$

$S: 10.36 € / t$

$\mathrm{W}: 1.36 € / \mathrm{t}$

F: $8.58 € / t$

$E: 4.73 € / t$

$P: 6.8 € / t$

Sp: $11 \overline{9} . \overline{8} \overline{\mathrm{E} / \mathrm{t}}$

$98.80 € / \mathrm{t}$

6.2. The second part of calculation has been focused on how the calculated price is influenced by the storage and warehouse period, the costs of financing of daily exchange rate differences, interest rates and foreign currencies.
Pc: $88 € / \mathrm{t}$
Wo: $0.1 € / \mathrm{t}$
Ir: $4 \%$
Bf: $0.4 € / \mathrm{t}$
Id: $4 \%$
P: $6.8 € / \mathrm{t}$
EXW
$94.40 € / t$

Sf: $0.76 € / \mathrm{t} / \mathrm{month}$

Ff: $0.88 € / \mathrm{t} / \mathrm{case}$

Ff: $0.88 € / \mathrm{t} /$ case

Ff: $0.88 € / \mathrm{t} / \mathrm{case}$

Wf: $0.14 € / \mathrm{t} / \mathrm{month}$

the calculation is seen below: 
Storage:

USD currency:

Interest rate:

\section{Calculated selling price:}

According to the result of this calculation, the additional costs have been returned on this price level. The futures price should be higher in order to
3 month

$0.8 € / \$$

$4 \%$

$100.20 € / t$

$125.25 \$ / \mathrm{t}$

realise higher profit with postponed selling, in comparison to prompt selling. The result of the calculation is shown in Table 1.

Results of the calculations (price in: $€$ or $\$ /$ ton)

\begin{tabular}{|c|c|c|c|c|c|c|c|c|c|c|c|}
\hline \multirow{2}{*}{$\begin{array}{c}\text { Macro } \\
\text { factor } \\
\text { Exch. rate }\end{array}$} & \multirow{2}{*}{$\begin{array}{c}\text { Micro } \\
\text { factor } \\
\text { Interest }\end{array}$} & \multicolumn{4}{|c|}{$\begin{array}{l}\text { Storage: } \\
\text { Short term (3 months) }\end{array}$} & \multicolumn{3}{|c|}{ Medium term (6 months) } & \multicolumn{3}{|c|}{ Long term (9 months) } \\
\hline & & & Pr+* & Pr0* & Pr-* & $\operatorname{Pr}+$ & Pr0 & Pr- & $\operatorname{Pr}+$ & Pr0 & Pr- \\
\hline \multirow{4}{*}{$\begin{array}{c}\mathbf{0 . 8 0} \\
€ / \$\end{array}$} & \multirow{2}{*}{$3.5 \%$} & $€$ & 100.04 & 99.65 & 99.27 & 104.77 & 104.00 & 103.23 & 110.39 & 109.23 & 108.08 \\
\hline & & $\$$ & 125.04 & 124.56 & 124.08 & 130.96 & 130.00 & 129.04 & 137.98 & 136.54 & 135.09 \\
\hline & \multirow{2}{*}{$4.5 \%$} & $€$ & 100.37 & 99.87 & 99.38 & 105.43 & 104.44 & 103.45 & 111.38 & 109.89 & 108.41 \\
\hline & & $\$$ & 125.46 & 124.84 & 124.22 & 131.79 & 130.55 & 129.31 & 139.22 & 137.36 & 135.51 \\
\hline 0.75 & $3.5 \%$ & $\$$ & 133.38 & 132.87 & 132.35 & 139.69 & 138.67 & 137.64 & 147.18 & 145.64 & 144.10 \\
\hline$€ / \$$ & $4.5 \%$ & $\$$ & 133.82 & 133.16 & 132.50 & 140.57 & 139.25 & 137.93 & 148.50 & 146.5 & 144.54 \\
\hline 0.85 & $3.5 \%$ & $\$$ & 117.69 & 117.24 & 116.78 & 123.26 & 122.35 & 121.45 & 129.86 & 128.51 & 127.15 \\
\hline$€ / \$$ & $4.5 \%$ & $\$$ & 118.08 & 117.49 & 116.91 & 124.04 & 122.87 & 121.71 & 131.03 & 129.28 & 127.54 \\
\hline
\end{tabular}

*Pr+: price fluctuation is +50 per cent during the whole storage period

*Pr0: no price fluctuation

*Pr-: price fluctuation is - 50 per cent during the whole storage period

\subsection{Evaluation of the results}

According to the result of the calculation in Table 1 it has been found that the additional costs of postponed selling in the first period ( 3 months) are increasing at a relatively fast rate because of the effect of once-paid costs, while in the next period, the increase of costs is under the linear level. After six months the increase of the costs is higher than on the linear level again, because of the higher percentage of interest and fumigation costs.

It has been found that the financing costs were reduced by time relatively, and that the possibility of a Pr0 situation has even been higher.

The effect of change in of the exchange rate of the foreign currency is determinative from the producer's (if postponed selling is chosen) point of view, independently of the length of postponed selling and the storage period. This price influence factor, however, can be managed by the futures hedge technique, as well.

There is no possibility to give a „unified answer" to the question of immediate or postponed selling or the length of the storage period in case of postponed selling. Choosing the „best solution” is the question of the independent business decision of liable market participants on the one hand, and the presented calculation information on the other hand.

Additional costs of postponed selling (especially the direct costs of public warehousing and futures hedge) do not influence heavily the cost of the transaction. Because of the facts above, these costs cannot be considered as hindering factors in development of reasonable salesmanship and price risk management strategy.

\section{CONCLUSIONS}

The calculation model developed can effectively establish business decisions in grain marketing. Using this model, there are several possibilities to make calculations for different business situations. The goal of this model is to give information for all the participants dealing with grain business. The model can present up-to-date information for business decisions based on daily figures.

The institutions, as futures market and public warehouse give a lot of possibilities in price risk management. According to the result of the calculations, it has been found that the effect of changing the rate of foreign currency is the strongest price influencing factor in cases of postponed selling, but it is also manageable in the futures market. Additional costs of using the market institutions cannot be considered as ,real obstacles” to engaging in these techniques.

Using the model, it is possible to analyse different price influence factors and to establish a long-term business strategy based on the opportunities offered by public warehousing and commodity exchange. 


\section{REFERENCES}

Bács, Z.-Kozár, L. (2002): (Facts about Public Warehousing) Amit a közraktározásról tudni kell. Szaktudás Ház Publisher, Budapest

Barancsuk, J. (1998): (Consumer Surplus) A fogyasztói többlet. Janus Pannonius University Press, Pécs

Bozzai, R. (1988): (Itiner for the Exchange) Tözsdekalauz. Magyar Tőzsdealapítvány, Budapest

Castle, E. N.-Becker, M. H.-Nelson, A. G. (1992): (Farm Business Management) Farmgazdálkodás. Mezőgazda Publisher Home, Budapest

Csőke, A. (1996): (Public Warehousing) A közraktározás. Közgazdasági és Jogi Publisher Home, Budapest

Fischer (1908): Die wirtschaftliche Entwicklung des Warrantverkhers in Europa u. Amerika, Berlin

Fodor, L. (2002): (Role of Exchanges in Price Formation and Liquidity of Agricultural Commodities) Tözsdék szerepe a mezőgazdasági termékek áralakításában, likviditásában. Ph.D. thesis, Kaposvár

Kelényi, Zs. (1994): (Legislation of Public Warehousing) A közraktározás hazai jogszabályi háttere. Kereskedelmi Jogi
Értesítő, 2. 7-8.

Kemény, G. (2001): (Analysis of Practice of Planning at Agribusineses of S. Dunantul) A tervezési gyakorlat elemzése a Dél-Dunántúli régió mezőgazdasági társas vállalkozásaiban. Ph.D. thesis, Kaposvár

Krugman, P. (1994): Competitiveness: a dangerous obsession. Foreign Affairs, 73.

Máygráber, Á. (1865): (The Dock system) A dockrendszer. Pest

Minch, K. (1928): Die Verkehrsreformen des deutschen Lagerscheins. Leipzig

Ortmaier, E. (1972): Zur lösung linearer stochastischer Optimierungsprobleme beider landwirtschaftlichen Betriebsplanung. Meisenheim (am Glan), Hain

Pennings, J. M. E.-Meulenberg, M. T. G. (1997): Hedging Risk in Agricultural Futures Markets. Boston, Kluwer Academic Publishers

Vajda, L. (2003): (Midterm supervision of CAP, Newest Developments of the Reform) A KAP félidejü felülvizsgálata és a reform legújabb szakasza. SZIE Conference, Budapest

Act of Commerce XXXVII., Budapest, 1875. 